\title{
TERMINOLOGIA ODNOSZĄCA SIĘ DO SYSTEMU POLITYCZNEGO WOLOFÓW W LE NAVIGAZIONI DI ALVISE DA CA'DA MOSTO E PIETRO DI SINTRA (C. 1465) AUTORSTWA ALVISE DA CA' DA MOSTO ${ }^{1}$
}

Rafał Smoleń $\odot$ http://orcid.org/0000-0003-0823-7195

Uniwersytet Warszawski

\section{ABSTRACT \\ TERMINOLOGY OF THE POLITICAL SYSTEM OF THE WOLOF PEOPLE IN LE NAVIGAZIONI DI ALVISE DA CA'DA MOSTO E PIETRO DI SINTRA (C. 1465) BY ALVISE DA CA' DA MOSTO}

The paper deals with Le navigazioni di Alvise da Ca'da Mosto e Pietro di Sintra, an account written circa 1465 by Alvise da Ca' da Mosto, a young Venetian merchant in the service of Henry the Navigator, describing his two voyages to the region of Senegambia taken in 1454 and 1455. The aim of the paper is to analyse the terminology used by Ca' da Mosto to describe the political system of the Wolof people as well as the factors that influenced his decisions in this regard. In this context, special attention will be paid to those fragments of the account which deal with the connection between the ruler and the state, the relationships of dependency between the Wolof countries as well as the socio-economic conditions in these countries.

Key words: Alvise da Ca' da Mosto, Wolof people, political terminology.

Słowa kluczowe: Alvise da Ca' da Mosto, Wolofowie, terminologia polityczna.

Le navigazioni di Alvise da Ca'da Mosto e Pietro di Sintra ${ }^{2}$ to relacja autorstwa 24-letniego weneckiego kupca w służbie Henryka Żeglarza - Alvise da Ca’ da Mosto.

1 Praca naukowa finansowana ze środków budżetowych na naukę w latach 2012-2016 jako projekt badawczy (DI 20110194 41) w ramach programu pod nazwą „Diamentowy Grant”.

2 Tytuł relacji można przetłumaczyć jako „Podróże morskie Alvise da Ca' da Mosto i Pietra di Sintry”. W języku polskim wyszła ona jako: A. da Ca' da Mosto, Podróże do Afryki, tłum. J. Szymanowska,

Adres do korespondencji: rafal.smolen@uw.edu.pl 
W części pierwszej opisuje on dwie swoje podróże morskie do Senegambii z lat 1455 i 1456, a w krótkiej części drugiej - podróż Portugalczyka Pedra de Sintry do Sierra Leone z 1460 roku (sam nie brał w niej udziału). Relacja, spisana około 1465 roku, a wydana w 1507 roku, stanowi pierwszy znany opis europejskiej wyprawy do Afryki Subsaharyjskiej, w której uczestniczył sam jego autor. Zawiera ona także pierwsze pisemne informacje o Wolofach - ludzie zamieszkującym obszar współczesnego północno-zachodniego Senegalu - barwnie ilustrujące ich życie społeczne, gospodarcze i polityczne. $\mathrm{Z}$ tych i innych względów Le navigazioni... jest uznawana za jedno z najważniejszych źródeł do historii wybrzeża Afryki Zachodniej w XV wieku oraz wczesnej europejskiej ekspansji zamorskiej. Równocześnie stanowi ona cenne źródło w badaniach porównawczych rozmaitych obszarów i epok historycznych ${ }^{3}$.

Przedmiotem niniejszego artykułu jest analiza terminologii stosowanej przez $\mathrm{Ca}$ ' da Mosto w odniesieniu do ustroju politycznego Wolofów, obecnej w opisach jego pierwszej i drugiej podróży. W tym kontekście istotne będą te fragmenty pierwszej części relacji, które odnoszą się do typu i charakteru organizacji politycznej Wolofów, związków między władcą a państwem, którym rządzi, oraz relacji zależności, zwłaszcza zwierzchności i podległości, między poszczególnymi organizmami politycznymi Wolofów. Głównym celem artykułu jest odpowiedź na pytanie, co zadecydowało o wyborach terminologicznych $\mathrm{Ca}$ ' da Mosto. W szczególności interesuje mnie to, jaką rolę w tym zakresie odegrały istniejące między Afrykanami a Europejczykami różnice w poziomie zamożności oraz sposobie organizacji politycznej i społeczno-gospodarczej.

\section{ALVISE DA CA' DA MOSTO I JEGO CZASY}

1. Alvise da Ca' da Mosto urodził się w 1432 roku w Wenecji w zubożałej rodzinie szlacheckiej. Jako kilkunastoletni chłopiec uczestniczył w wyprawach galer weneckich do Afryki Północnej i Północno-Zachodniej, na Kretę i do Flandrii. Nie

wstęp i oprac. M. Tymowski, Gdańsk 1994 (dalej: Ca' da Mosto - Podróże). Na potrzeby niniejszego artykułu korzystałem, poza wydaniem polskim, z dwóch wydań tej relacji w języku włoskim: A. da Ca' da Mosto, Le navigazioni di Alvise da Ca'da Mosto e Pietro di Sintra [w:] G.B. Ra musio, Navigazioni e viaggi, t. 1, a cura di M. Milanesi, Torino 1978, s. 461-542; idem, Il viaggio di Giovan Leone e le navigazioni di Alvise da Ca da Mosto, di Pietro di Cintra, di Annone, di un piloto portoghese e di Vasco di Gama, Venezia 1837. Po cytatach z relacji podałem w nawiasach numery stron, z których one pochodzą pierwsza liczba odnosi się do wydania polskiego ( $\mathrm{Ca}$ ' da Mosto - Podróże), druga zaś do oryginalnego wydania włoskiego pod red. Mariki Milanesi. Tę samą technikę zastosowałem w przypadku odwołań do relacji niebędących cytatami.

3 Na wartość tej relacji w badaniach komparatystycznych zwracał uwagę Marian Małowist: „Szkoda, że tekst ten nie był wykorzystany przez naszych uczonych w okresie badań nad tysiącleciem państwa polskiego, pozwala bowiem przez zastosowanie metody porównawczej lepiej zrozumieć początki feudalnej państwowości także i w Europie”. M. Małowist, Konkwistadorzy portugalscy, Warszawa 1976, s. 122-123. 
wiemy nic o szkołach, jakie kończył, ale bez wątpienia był on człowiekiem wykształconym ${ }^{4}$. W czasie wypraw uczył się fachu żeglarskiego i kupieckiego oraz sztuki wojennej (jako kusznik na galerach), poznawał nowe języki, zdobywał wiedzę z zakresu geografii, astronomii i nawigacji.

W 1454 roku Ca' da Mosto wyruszył w swoją drugą podróż morską do Flandrii, aby wzbogacić się na handlu i odzyskać dobre imię swojej rodziny, nadszarpnięte przez intrygi polityczne i finansowe. W okolicach Przylądka Świętego Wincentego wiatry zepchnęły go na wybrzeże, gdzie wysłannicy Henryka Żeglarza, uciekając się do manipulacji w opisie możliwych profitów, zaproponowali mu udział w wyprawie do Afryki $(6-10,256-257)^{5}$.

W pierwszej połowie lat 50 . XV wieku portugalskie wyprawy wzdłuż zachodniego wybrzeża Afryki, po wielu latach strat, zaczęły wreszcie przynosić zyski. Henryk Żeglarz nie był już tak osamotniony w swoich planach ekspansji zamorskiej jak jeszcze kilkanaście lat wcześniej ${ }^{6}$. Na jego dworze w Sagres systematycznie gromadzono wiadomości o Afryce i Afrykanach ${ }^{7}$. Korzystano przy tym z różnorodnych źródeł - zbierano raporty odkrywców, przesłuchiwano afrykańskich niewolników oraz wolnych Afrykanów, którzy począwszy od lat 40., wraz z rozwojem handlu, coraz częściej wchodzili na karawele i płynęli do Portugalii ${ }^{8}$. W połowie lat 50., jak również przez długi czas później, wiadomości o Afryce, podobnie zresztą jak te o Azji, docierały przede wszystkim do ludzi władzy, kupców i ludności miejskiej.

4 Tak Michał Tymowski we wstępie do: Ca' da Mosto - Podróże, s. VIII.

5 Marian Małowist pisze wręcz o „oszustwie”. Zob. M. Małowist, Konkwistadorzy portugalscy, s. 118. Później do wyprawy do Afryki Wenecjanina zachęcał osobiście Henryk Żeglarz.

6 O osamotnieniu infanta $\mathrm{w}$ jego planach ekspansji zamorskiej oraz obawach portugalskich dostojników przed wysłaniem wyprawy do Gwinei pisali kilkadziesiąt lat później: Rui de Pina, Chronica del Rey Dom João II [w:] J.W. Blake, Europeans in West Africa 1450-1560, t. 1-2, London 1967, s. 70; João de Barros, Décadas da Ásia [w:] G.R. Crone, The Voyages of Ca da Mosto and Other Documents on Western Africa in the Second Half of the Fifteenth Century, London 1936, s. 115. Istnieje również obszerna literatura podważająca wielkość zasług Henryka Żeglarza na rzecz portugalskiej ekspansji w Afryce. W tym kontekście interesujące są uwagi Mariana Małowista dotyczące przesadnej koncentracji badaczy na osobie infanta, zawarte w jego książce Europa a Afryka Zachodnia w dobie wczesnej ekspansji kolonialnej, Warszawa 1969, s. 31.

7 Co potwierdzałyby słowa samego Ca’ da Mosto, który tak pisze o „,nowych krajach” za Przylądkiem Zielonym: „Jeszcze przed moim wyjazdem z Portugalii dowiedziałem się bowiem o ich istnieniu od pana infanta, który jest osobą informowaną co jakiś czas o sprawach dotyczących krainy Murzynów" (51, 276).

Część, jeśli nie większość z nich, robiła tak dobrowolnie i z ciekawości, inni z polecenia swoich zwierzchników (wspólnoty plemiennej, władcy), ze względów politycznych lub wywiadowczych. W latach 40 . były to przypadki sporadyczne, jednak już w kolejnej dekadzie, po nawiązaniu regularnych kontaktów handlowych, stały się one znacznie częstsze. „Ludzi takich przyjmowano dobrze, gdyż mogli być dla Portugalczyków cennym źródłem informacji. Po rozmowach i przekazaniu im darów odsyłano ich do Afryki". M. Ty mow ski, Podróże i poselstwa władców zachodnioafrykańskich do Portugalii w XV w., „Afryka” 2014, nr 40, s. 32. Dodajmy jednak, że część Afrykanów, którzy wchodzili na karawele, po zapoznaniu się z przybyszami i wymianie towarów schodziła na ląd. 
Najczęściej były one związane $\mathrm{z}$ handlem i dopiero w tym kontekście odnosiły się one do organizacji politycznej miejscowych ludów9

Opowieści o przylądku Non czy mitycznych potworach morskich nie były dla Ca' da Mosto zupełnie bez znaczenia, nie można jednak przeceniać ich wagi, tym bardziej że sam autor, zazwyczaj szczery i prostolinijny, nie wspomina o nich w swojej relacji. Słusznie podkreśla się, że wraz z postępem odkryć geograficznych strach przed dalekimi podróżami, oparty na irracjonalnych obrazach końca świata, był zastępowany obawami związanymi z nawigacją, nieprzychylnym klimatem, chorobami i walkami z napotkanymi ludami ${ }^{10}$. Dotychczasowa wiedza i doświadczenie, a także szczególne cechy charakteru Wenecjanina powodowały jednak, że tego rodzaju obawy nie były w stanie zniechęcić go do propozycji Henryka Żeglarza. Wcześniej, jak już była mowa, wielokrotnie pływał on do portów północnoafrykańskich, znał opowieści z dotychczasowych wypraw wzdłuż zachodniego wybrzeża tego kontynentu, z pewnością zetknął się z relacją Marca Polo, a być może także relacją Jana del Piano CarPiniego z podróży do Mongołów, przede wszystkim jednak był człowiekiem ciekawym świata, żądnym przygód, sławy i zysku, zdecydowanym i gotowym na ryzyko ${ }^{11}$.

Ca' da Mosto porzucił więc znaną i bezpieczną drogę na północ, gdzie czekał go pewny zarobek, na rzecz ryzykownej, choć potencjalnie znacznie bardziej zyskownej podróży w nieznane. Sam pisze o tym w taki sposób: „I naprawdę, usłyszawszy to wszystko, a byłem przecież młody i odporny na trudy, spragniony ujrzenia na świecie rzeczy, których nie oglądał nikt z moich rodaków, żywiłem też nadzieję na dobrą sławę i zarobek, powziąłem decyzję wyruszenia w tamte strony" $(10,257)^{12}$.

2. Podróże Ca' da Mosto wpisywały się w nowy model portugalskiej polityki zamorskiej. Pierwotnie portugalskie wyprawy do Afryki stanowiły de facto przedłużenie rekonkwisty i pod wieloma względami przypominały działania pirackie portugalscy żołnierze w pełnym rynsztunku wysiadali na ląd z okrzykiem: „Święty Jakub, Święty Jerzy, Portugalia!”, po czym siłą chrzcili miejscową ludność, grabili

9 Zob. M. Tymowski, Odkrywanie świata przez Europejczyków w XIV-XV w. [w:] Schyłek średniowiecznej Europy, red. H. Samsonowicz, Warszawa 2003, s. 270-271; M. Małowist, Europa a Afryka Zachodnia..., s. 138-143 i n.

10 M. Tymowski, Strach i odwaga w czasie pierwszych wypraw europejskich do Afryki $w X V$ w., „Przegląd Historyczny” 2006, nr 97, z. 3.

11 Obawy i pragnienia, jakie mogły targać 24-letnim żeglarzem, dobrze oddają słowa Pietera de Mareesa, holenderskiego pisarza i żeglarza, który wyruszył do Afryki 150 lat później, zawarte we wstępie do jego relacji. Zob. P. de Marees, Description and Historical Account of the Gold Kingdom of Guinea (1602), ed. and transl. A. van Dantzig, A. Jones, Oxford 1987, s. 4.

12 W innych miejscach Ca’ da Mosto pisze: „Pewnym jest, że podążyłem w głąb lądu [do siedziby Budomela] kierując się w nie mniejszym stopniu pragnieniem zobaczenia i poznania nowych rzeczy, niżeli chęcią otrzymania należnej mi zapłaty” $(37,269)$; „Zatem ja, powodowany pragnieniem znalezienia złota, a także zobaczenia różnych rzeczy, zostawiając za sobą Budomel, wsiadłem na karawelę i od razu rozwinąłem żagle, by jak najrychlej oddalić się od wybrzeża" $(51,276)$. Ca' da Mosto miał 24 lata, gdy wyruszał do Afryki. Chociaż w realiach XV w. był on już zatem człowiekiem dojrzałym, sam uważał się, jak wskazuje jeden z powyższych cytatów, za człowieka młodego (twierdząc zresztą, że ma 22 lata). Zob. Ca' da Mosto - Podróże, s. VIII. 
jej dobytek i brali niewolników ${ }^{13}$. Mniej więcej w połowie lat 40. XV wieku Henryk Żeglarz uznał jednak, że tak zwane razzias w sensie ekonomicznym opłacają się jedynie na krótką metę i przyjął bardziej długofalowe, strategiczne podejście (Ivana Elbl ujęła to obrazowo: traders rather than raiders ${ }^{14}$ ). Najlepszym wyrazem tej zmiany było wzniesienie w 1448 roku fortu i faktorii na wyspie Arguim, co miało ustabilizować i zintensyfikować portugalsko-afrykańską wymianę handlową, a także umocnić pozycję Portugalczyków na wybrzeżu.

$\mathrm{Ca}^{\prime}$ da Mosto nie był pierwszym Europejczykiem, który dotarł na południe od rzeki Senegal. Dekadę wcześniej, w 1445 lub 1446 roku, Portugalczyk Dinis Dias dopłynął do położonego przeszło 200 kilometrów dalej Przylądka Zielonego ${ }^{15}$. Dzięki temu na dworze w Sagres wiedziano, że zamieszkujący te tereny Wolofowie tworzyli kilka niewielkich organizacji politycznych. W latach 1445-1455 Portugalczycy nawiązali z nimi kontakty handlowe, szczególnie intensywne z nadbrzeżnym Kaiorem. Ważne miejsce w planach Henryka Żeglarza zajmował także położony w głębi lądu Dżolof - współpraca z tym krajem miała ułatwić nawiązanie stosunków z położoną jeszcze głębiej silną Mali. W Atlasie katalońskim z 1375 roku władca Mali, mansa Musa, został przedstawiony z samorodkiem złota $\mathrm{w}$ ręku - te $\mathrm{i}$ inne wyobrażenia i opowieści, takie jak słynne podanie o legendarnym państwie księdza Jana, motywowały Portugalczyków do dalszej ekspansji w Afryce. To właśnie w tym kontekście należy widzieć obie wyprawy $\mathrm{Ca}$ ' da Mosto - choć sam żeglarz nie wspomina o tym wprost, to ich podstawowym celem, z punktu widzenia interesów infanta i korony portugalskiej, było pogłębienie wymiany handlowej i zbadanie szans nawiązania sojuszu politycznego z Wolofami i innymi ludami w Afryce Zachodniej, przede wszystkim przeciw muzułmanom w północnej Afryce ${ }^{16}$.

Równocześnie na południe od Przylądka Zielonego Portugalczycy wciąż mieli złą reputację, budzili nieufność, a nawet wrogość części Afrykanów ${ }^{17}$. Widać to także na kartach Le navigazioni, która (jako opis wypraw z przejściowego okresu połowy

13 Zob. M. Tymowski, Wenecka uczta na wybrzeżu Afryki Zachodniej w polowie XV wieku [w:] Aetas media, aetas moderna. Studia ofiarowane profesorowi Henrykowi Samsonowiczowi w siedemdziesiata rocznice urodzin, red. H. Manikowska, A. Bartoszewicz, W. Fałkowski, Warszawa 2000, s. 588. W tym kontekście szczególnie interesujący jest zawarty w kronice Zurary opis konfrontacji Europejczyków z Afrykanami, w której zginął duński żeglarz Valarte. Zob. G.E. Zurara, The Chronicle of the Discovery and Conquest of Guinea, oprac. Ch. Beazley, London - New York 1896, rozdz. XCIV. Zob. także rozdz. XXXII tej kroniki, w której autor opisuje odmowę kontaktu. M. Tymowski, Europeans and Africans in the Early Period of Portuguese Expansion in Africa - the Organization and Course of the First Encounters, „Hemispheres” 2010, vol. 25.

14 I. Elbl, Cross-Cultural Trade and Diplomacy: Portuguese Relations with West Africa, 14411521, „Journal of World History” 1992, vol. 3, no. 2.

15 M. Tymowski, Wolof Economy and Political Organization: The West African Coast in the Mid-Fifteenth Century [w:] Early State Economics, ed. H.J.M. Claessen, P. van de Velde, New Brunswick-London 2009, s. 132.

16 Michał Tymowski pisze: „Wybór padł na Wolofów, jeden z ludów, z którym Portugalczycy zetknęli się już nieco wcześniej. [...] aby kontakty stały się trwałe, należało dobrze poznać przyszłych partnerów. Takie właśnie zadanie otrzymał Ca' da Mosto”. M. Tymowski, Wenecka uczta ..., s. 598. Zob. idem, Podróże i poselstwa ..., s. 25.

17 Zob. M. Tymowski, Strach i odwaga..., s. 340-345. 
lat 50.) ilustruje całe spektrum pierwszych kontaktów Europejczyków i Afrykanów znajdziemy tam przykłady spotkań pokojowych ${ }^{18}$, nieumiejętności nawiązania kontaktu $^{19}$, a także odmowy kontaktu i walki podejmowanej przez Afrykanów ${ }^{20}$. Dużą przeszkodą w nawiązaniu dobrych stosunków w regionie Senegambii, co najmniej do połowy lat 50., był brak thumaczy (na co nieraz wskazuje sam Ca' da Mosto) ${ }^{21}$.

3. Ca' da Mosto spisał, a raczej podyktował swoją relację najprawdopodobniej w latach 1464-1465, na podstawie wspomnień, a także, być może, notatek, jakie sporządził w czasie swoich dwóch pierwszych podróży. Opisując podróż Pedra de Sintry, w której sam nie brał udziału, opierał się na opowieści znajomego kapitana okrętowego, potwierdzonej przez dowódcę tej wyprawy. Niestety do naszych czasów nie zachował się oryginalny rękopis Wenecjanina. Jego treść znamy z dwóch odpisów, między którymi istnieją jednak pewne różnice. Rękopis A powstał między 1464 a 1507 rokiem i został udostępniony naukowcom dopiero w 1928 roku. Późniejszy rękopis B został sporządzony prawdopodobnie przez anonimowego franciszkanina, który wprowadził do niego liczne negatywne uwagi o kobietach i Afrykanach (co z pewnością nie odzwierciedlało intencji Ca' da Mosto, który był pozbawiony tego

$18 \mathrm{Ca}$ ' da Mosto wielokrotnie wspomina o pokojowych celach żeglarzy, np.: „Otrzymali rozkaz, że gdyby przypadkiem pojawiły się murzyńskie łodzie i próbowały ich atakować, mają natychmiast uciekać na statek, nie wdając się w żadne zwady. Przybyliśmy bowiem do tego kraju po to, aby zawrzeć z jego mieszkańcami pokój i przymierze oraz zdobyć ich przychylność, tego zaś nie osiąga się siłą, lecz rozumem" (56, 278). Zob. także: s. 56-59 (278-280), 66-67 (284), 70-71 (286), 73-74 (287-288).

19 Najczęściej ze względu na przeszkody językowe. Przykładowo Ca' da Mosto opisuje, jak pod koniec swojej drugiej podróży (w okolicach Wysp Bissagos) tłumacze dwukrotnie, za każdym razem bez powodzenia, próbowali nawiązać rozmowę z Afrykanami. „Wreszcie, nie mogąc się z nimi dogadać i wnosząc $\mathrm{z}$ tego, że znaleźliśmy się w całkiem nowym kraju, gdzie żadne porozumienie nie będzie już możliwe, uznaliśmy, że dalsza droga naprzód nie ma sensu; i sądząc, że nic tam po nas, gdyż odtąd będziemy napotykać coraz to nowe narzecza, postanowiliśmy wracać” $(74,288)$. Zauważmy, że Wenecjanin używa słowa linguaggi (,narzecza”), a nie lingue (języki). Zob. J. Mantel-Niećko, Języki Afryki [w:] Historia Afryki do początku XIX wieku, red. M. Tymow ski, Wrocław 1996, s. 38-39. Jeszcze więcej problemów w nawiązaniu kontaktu, wynikających z przeszkód językowych, miał Pedro de Sintra, który w okolicach Sierra Leone dwukrotnie, również bez powodzenia, próbował się porozumieć z Afrykanami, a nawet, inaczej niż Ca' da Mosto, nie zdołał nic kupić $(75,277)$.

20 Opis walki znajdziemy np. na s. 57-59 (279-280). Odmowę kontaktu ilustruje między innymi następujący fragment: „W odpowiedzi na to wszystko usłyszeliśmy, że w przeszłości docierały do nich jakieś informacje o nas i o naszym handlu z Murzynami z Senegalu, którzy jednak ponad wszelką wątpliwość są złymi ludźmi, skoro godzą się na naszą przyjaźń. Oni sami uważają bowiem za rzecz pewną, że my, chrześcijanie, jadamy ludzkie mięso i kupujemy Murzynów tylko po to, żeby ich w ten sposób pozbawiać życia. Dlatego za nic w świecie nie życzą sobie naszej przyjaźni; wręcz przeciwnie, pragną nas wszystkich pozabijać, a potem z naszych rzeczy zrobić prezent swojemu panu" $(59,280)$.

${ }_{21}$ Portugalczycy z łatwością nawiązywali natomiast kontakt na wybrzeżu Mauretanii (było sporo thumaczy z arabskiego i berberskiego). Zob. M. Tymowski, Jak $w$ XV wieku europejscy odkrywcy porozumiewali się z Afrykanami? [w:] Człowiek w społeczeństwie średniowiecznym, red. R. Michałowski, Warszawa 1997; idem, Opinie Afrykanów o Europejczykach we wczesnym okresie wypraw portugalskich do Afryki Zachodniej (XV w.-poczatek XVI w.) [w:] Ex Africa semper aliquid novi, t. I, red. J. Łapott, E. Prądzyńska, Żory 2014, s. 66-73 i n.; I. Elb1, Cross-Cultural Trade and Diplomacy ..., s. 169. 
rodzaju uprzedzeń) ${ }^{22}$. Kolejni kopiści i wydawcy wprowadzili do tych rękopisów podział na rozdziały, opatrywali je nieraz bardzo treściwymi tytułami, zmieniali kolejność poszczególnych części tekstu.

Mimo że po śmierci Henryka Żeglarza w 1460 roku liczba oficjalnych wypraw portugalskich do Afryki gwałtownie spadła, a król Alfons V (panujący w latach 1438-1481), poniekąd wbrew swojemu przydomkowi „Afrykańczyk”, koncentrował swoją uwagę na Maroku i Półwyspie Iberyjskim, Portugalczycy przez siedem lat (do 1463 r.) wstrzymywali powrót $\mathrm{Ca}^{\prime}$ da Mosto do Wenecji ${ }^{23}$. Na dworach w Sagres i Lizbonie świetnie zdawano sobie sprawę z wartości jego relacji - wiadomości dotyczące systemu rządów Wolofów i sąsiednich ludów, szans nawiązania kontaktów politycznych i handlowych, podobnie zresztą jak te dotyczące języków, żeglugi czy geografii nowych lądów, były wyjątkowo cenne także dla innych państw europejskich, co więcej, mogłyby je zachęcić do podjęcia rywalizacji z Portugalczykami (a na pewno im ją ułatwić) $)^{24}$.

W latach 60. XV wieku Europejczycy odkryli Sierra Leone, a w pierwszej dekadzie kolejnego stulecia znali już kontury całego kontynentu ${ }^{25}$ (choć ich obecność tam wciąż ograniczała się do wybrzeża). Naturalnie wraz ze wzrostem wiedzy o Afryce wartość poznawcza relacji Ca' da Mosto, zwłaszcza w sprawach praktycznych, takich jak żegluga czy nawigacja, zaczęła maleć. Ostatecznie relacja ta została wydana drukiem na podstawie rękopisu A oraz jakiegoś innego, dziś już zaginionego, w 1507 roku - a więc 42 lata od powstania pierwszego rękopisu i 24 lata po śmierci jej autora - w Vicenzy, w ramach zbioru różnorodnych opisów podróży (wcześniej jednak, w 1490 r., w Wenecji wydano portulan, który Ca' da Mosto sporządził w trakcie jednej ze swoich podróży). W XVI wieku Le navigazioni cieszyły się dużą popularnością i były wielokrotnie wznawiane (w ramach większych zbiorów podróżniczych), zarówno po włosku, jak i w tłumaczeniach na inne języki² ${ }^{26}$.

22 M. Tymowski, Wenecka uczta..., s. 599.

23 Zob. Ca' da Mosto - Podróże, s. X; J.G. Da Silva, Morskie dzieje Portugalczyków, tłum. V. Soczewińska, red. nauk. J. Kieniewicz, Gdańsk 1987, s. 292; G.H.T. Kimble, Portuguese Policy and Its Influence on Fifteenth Century Cartography, „Geographical Review” 1933, vol. 23, no. 4.

24 Również Henryk Żeglarz trzymał w tajemnicy część informacji zdobytych w wyniku wypraw morskich do Afryki oraz wizyt Afrykanów w Portugalii. Prawdopodobnie niewiele z nich przeniknęło do kroniki Zurary i innych tekstów z tamtych czasów. Zob. M. Tymowski, Podróże i poselstwa ..., s. 19.

${ }_{25}$ Zob. mapa świata według Alberta Cantina z 1502 r., np. w P. Whitfield, The Image of the World: 20 Centuries of World Map, London 2010, s. 44-45. Dobrej ilustracji postępów w ogólnej znajomości geografii Afryki dostarczają ówczesne informacje o jej największych rzekach. Ca’ da Mosto pisał: „Uczeni ludzie powiadają, że owa rzeka [Senegal] jest jedną z odnóg rzeki Gehon [...]. Innym ramieniem Gehonu jest Nil [...]. Tak twierdzą ludzie, którzy badali świat” (29-30, 266). Już jednak na mapie Contariniego z 1506 r. widzimy, że Nil i Niger nie łączą się ze sobą (P. Whitfield, op. cit., s. 46-47).

${ }_{26}$ Najczęściej wznawiane, cytowane i tłumaczone było drugie wydanie tej relacji, zawarte w zbiorze różnorodnych relacji z podróży z 1550 r., który opracował Giovanni Battista Ramusio, opierając się na rękopisie A lub innym bardzo do niego podobnym (z pewnością znał on także rękopis B i wydanie z 1507 r.). Polskie Podróże do Afryki zostały przygotowane na podstawie ostatniego włoskiego wydania Ramusia z 1550 r., opracowanego w 1978 r. przez Marikę Milanesi. Joanna Szymanowska i Michał Tymowski korzystali również z rękopisu A, który został krytycznie opracowany w 1966 r. przez Tullię 
4. Le navigazioni to relacja spisana przez osobę spostrzegawczą, wnikliwą, krytyczną i zasadniczo pozbawioną uprzedzeń, charakterystycznych dla wielu wcześniejszych (Zurara) i późniejszych opisów Afryki. Autor często wskazuje, kto jest jego informatorem, dzieli się także swoimi wątpliwościami co do wiarygodności przedstawianych informacji ${ }^{27}$. Dzięki temu jest to źródło stosunkowo wiarygodne. Le navigazioni jest przy tym niezwykle treściwa - Wenecjanin interesuje się niemal każdą ważniejszą dziedziną życia Afrykanów, od polityki przez kulturę po technikę i przyrodę, wiele z nich, jak w przypadku Wolofów, opisując w sposób zarazem wszechstronny i szczegółowy. Jego relacja jest przy tym niezwykle barwna i zajmująca, utrzymana w stylu nieomal reportażowym. Dotyczy to w szczególności opisu pierwszej podróży, w którym autor chętnie dzieli się z czytelnikiem swoimi emocjami-zdziwieniem, zachwytem, zniesmaczeniem, a nawet oburzeniem.

\section{WYBRZEŻE AFRYKI ZACHODNIEJ W XV WIEKU}

„Kraina Murzynów żyjących nad rzeką Senegal jest pierwszym murzyńskim królestwem w Dolnej Etiopii, a ludy zamieszkujące brzegi tej rzeki nazywają się Wolofami [Gilofi]" - pisze Ca' da Mosto $(30,266)$. W opisie Wolofów autor skupia się na dwóch organizmach politycznych położonych w połowie drogi między rzeką Senegal a Przylądkiem Zielonym. Pierwszym z nich jest regno di Senega (w polskim wydaniu „królestwo Senegalu”), na czele którego stoi „dwudziestodwuletni młodzieniec imieniem Zucholin” (re di Senega, „król Senegalu”) (30, 266), drugim zaś kraj pana o imieniu Budomel (autor stosuje zróżnicowane terminy na określenie tego organizmu politycznego).

Ca' da Mosto ma zróżnicowaną wiedzę na temat obu władców. Wiadomości o Zucholinie, jakimi dysponuje, pochodzą wyłącznie z drugiej ręki. Z Budomelem autor spotyka się zaś osobiście, w dodatku wiedząc „od pewnych Portugalczyków, którzy mieli z nim do czynienia, że jest on przyzwoitą i godną zaufania osobą i że płaci za towar zgodnie z jego rzeczywistą wartością" $(36,268)^{28}$. Budomel zaprasza kupca do swojej siedziby w głębi lądu (,ponieważ wiedziałem, jak dobrą sławą się cieszy,

Gasparrini Leporace. Zob. Ca' da Mosto - Podróże, s. XII-XVI; P. Hair, Early Sources on Guinea, „History in Africa” 1994, vol. 21, s. 98-100.

27 Na przykład: „W owym miejscu Budomel miał (jeśli się nie mylę) dziewięć żon” (39, 270).

${ }_{28}$ W innym miejscu Ca' da Mosto stwierdza: ,pewien godny wiary Genueńczyk opowiedział mi, że gdy rok przede mną znalazł się w kraju Budomela i spał kiedyś w domu jego bratanka Bisborora, gdzie potem i mnie ulokowano, [tenże Bisboror odprawiał] pewne zaklęcia [...]. Zadziwiło to Genueńczyka, a wtedy Bisboror powiedział mu, że nie ma się czemu dziwować, gdyż jego wuj Budomel odprawia o wiele większe czary. Gdy pragnie on sporządzić truciznę do swej broni, zakreśla wielkie koło, do którego czarami i zaklęciami sprowadza wszystkie węże z okolicy; tego, który wydaje mu się najbardziej jadowity, własnoręcznie zabija, a pozostałym pozwala odejść. Wytoczywszy z niego krew, rozciera ją następnie $z$ nasionami pewnego drzewa (widziałem te nasiona i nawet ich trochę miałem) i sporządziwszy z tego miksturę, zatruwa nią swoją broń - a ktokolwiek zostaje nią raniony, to mimo że uchodzi z niego tylko trochę krwi (bo rana jest mała), umiera po kwadransie" $(45-46,273)$. 
przystałem na jego zaproszenie, on zaś ugościł mnie z wielką serdecznością" - 37, 269), tam zaś, okazując sobie wiele zaufania i życzliwości, panowie dokonują transakcji handlowej, wymieniając między innymi konie za niewolników ${ }^{29}$, dzielą się wiadomościami o swoich krajach, a nawet prowadzą, opartą na racjonalnych argumentach, dyskusję teologiczną o wadach i zaletach islamu i chrześcijaństwa. Ca' da Mosto spędził w kraju Budomela co najmniej miesiąc ${ }^{30}$, dzięki czemu jego opis jest wszechstronny i bardzo szczegółowy.

Większość obszaru między rzeką Senegal a współczesną granicą Gambii z Senegalem w połowie XV wieku była zamieszkana przez Wolofów i Sererów ${ }^{31}$. Źródła pisane z okresu od XVI do XVIII wieku oraz tradycje ustne zebrane w XIX i XX wieku wskazują, że w połowie XV stulecia Wolofowie tworzyli cztery organizmy wczesnopaństwowe - Dżolof, Kaior, Walo i Bawol ${ }^{32}$. Najstarszy, powstały w XIII wieku

29 Z punktu widzenia Ca' da Mosto nie była to do końca udana transakcja, ponieważ Budomel nie był w stanie zaoferować mu upragnionego złota (51, 276). Marian Małowist twierdzi, że kupiec ,doznał poważnego zawodu”. Zob. M. Małowist, Konkwistadorzy portugalscy, s. 122.

30 Sam autor podaje, że spędził 28 dni w wiosce zarządzanej przez Bisborora, położonej ok. czterech mil od głównej siedziby Budomela. Pisze on: ,przez ten czas wielekroć odwiedzałem pana Budomela, a bratanek zawsze mi asystował” $(38,269)$. Stwierdza, że wracał nad rzekę Senegal drogą lądową, ponieważ pogoda popsuła się tak bardzo, że uniemożliwiała żeglugę.

31 Zob. Ca' da Mosto - Podróże, mapa na s. 31; M. Tymowski, Przestrzenne ramy handlu europejsko-afrykańskiego na Wybrzeżu Zachodnim Afryki w XV i na początku XVI wieku (opisy i źródła ikonograficzne) [w:] Świat średniowiecza. Studia ofiarowane Profesorowi Henrykowi Samsonowiczowi, red. A. Bartoszewicz, G. Myśliwski, J. Pysiak, P. Żmudzki, Warszawa 2010.

32 Pojęcie wczesnego państwa (early state), podobnie jak wodzostwa czy systemu segmentarnego, od dawna stanowi przedmiot sporów wśród historyków, antropologów, politologów i przedstawicieli innych dyscyplin naukowych, zresztą nie tylko w ramach afrykanistyki. W latach 70. XX w. Henri J.M. Claessen i Peter Skalník stworzyli międzynarodową grupę naukowców w celu zbadania zagadnienia kształtowania się państwa, zdefiniowania różnic między państwową a niepaństwową formą organizacji politycznej oraz określenia szczegółowych cech organizacji wczesnopaństwowej w perspektywie, jak powiedziałaby Ewa Domańska, światodziejowej. Rezultatem prawie dwudziestoletniej pracy tej grupy jest kilka publikacji dotyczących problemów politycznych, gospodarczych i ideologicznych we wczesnych państwach: The Early State (1978) i The Study of the State (1981) (obie pod red. H.J.M. Claessena i P. Skalníka), Development and Decline (1985) (pod red. H.J.M. Claessena, P. van de Veldego i M.E. Smitha), Early State Dynamics (1987) i Early State Economics (1991) (obie pod red. H.J.M. Claessena i P. van de Veldego), Ideology and the Formation of Early States (1996) (pod red. H.J.M. Claessena i J.G. Oostena). Podsumowaniem tej serii są prace teoretyczne Claessena: Structural Change: Evolution and Evolutionism in Cultural Anthropology (2000) i Was the State Inevitable? Social Evolution \& History (2002). Omówienie sporów, jakie pojawiły się w związku z pojęciem wczesnego państwa, przekracza ramy tego artykułu, warto jednak, jak sądzę, zasygnalizować kilka problemów związanych z mechanizmami zmiany typu i charakteru organizacji politycznej przedkolonialnych społeczności afrykańskich. Wczesne państwo stanowi organizację, w ramach której funkcjonują struktury typu państwowego i plemiennego. Proces powstawania państw w Afryce, podobnie jak w wielu innych miejscach świata, nie musiał się wiązać z likwidacją instytucji przedpaństwowych, w tym plemiennych. W wielu przypadkach państwo stanowiło nadbudowę nad strukturą przedpaństwową, co mogło się przejawiać w decentralizacji władzy i powierzeniu jej dotychczasowym naczelnikom rządów na szczeblu lokalnym, np. w nowo utworzonych prowincjach państwa. Nie wszystkie organizmy bezpaństwowe przekształcały się w państwowe, wczesne państwo miewało charakter nietrwały, a proces powstawania państw bywał odwracalny. W tym kontekście warto wspomnieć, że organizmy wodzowskie, podobnie jak systemy segmentarne i inne organizmy niepaństwowe w Afryce, nieraz funkcjonują w literaturze, zwłaszcza starszej, jako 
Dżolof co najmniej od końca XIV wieku sprawował zwierzchność nad pozostałymi organizmami politycznymi Wolofów ${ }^{33}$. Dżolof uzależnił od siebie także organizmy Sererów (Sine i Salum), położone na południe od obszaru Wolofów, a także złotonośny teren Bambuk, wcześniej pod zwierzchnictwem Mali ${ }^{34}$.

Wolofowie tworzyli system wielkich rodzin i byli podzieleni na klany o zróżnicowanym znaczeniu i prestiżu. Władcy mieli wiele żon i liczne potomstwo, co sprawiało, że liczba pretendentów do tronu zawsze była duża ${ }^{35}$. Władcy ci nie pobierali regularnych podatków od ludności, otrzymywali jedynie zwyczajowe dary. Zdaniem Michała Tymowskiego wynikało to nie tylko ze słabości miejscowej gospodarki, cechującej się niewielkimi nadwyżkami, ale także z tego, że władza u Wolofów była wybieralna, a nie dziedziczna. Autor wyróżnia przy tym dwa powody, które zdecydowały o ukształtowaniu się państwa i podstaw systemu gospodarczego Wolofów. Pierwszym z nich było stworzenie enklaw kontrolowanych i wykorzystywanych przez grupę rządzącą (w Kaiorze i Dżolofie były one zarządzane przez żony władcy, a niewolnicy produkowali tam żywność dla elity), drugim zaś - przeniesienie części ciężaru związanego ze stworzeniem państwa poza jego obszar, poprzez handel zagraniczny lub najazdy na sąsiednie państwa. Wszystkie te działania, będąc ze sobą

\footnotetext{
„organizacje przedpaństwowe”. Stosowanie w odniesieniu do nich terminu „przedpaństwowy”, w innym celu niż do opisu ewolucji określonego organizmu państwowego, jest mylące i stanowi wyraz ewolucjonizmu historycznego, podobnie jak określanie społeczności afrykańskich mianem „ludów przedpiśmiennych". Zob. M. Tymowski, Państwa Afryki przedkolonialnej, Wrocław 1999; idem, Państwo i plemię w dziejach Afryki Czarnej [w:] Plemię, państwo, demokracja. Uwarunkowania kultury politycznej w krajach pozaeuropejskich, red. R. Vorbrich, Poznań 2007; idem, State and Tribe in the History of Medieval Europe and Black Africa - a Comparative Approach, „Social Evolution and History" 2008, vol. 7, no. 1, s. 171-196; A. Southa1l, The Segmentary State: From the Imaginary to the Material Means of Production [w:] Early State Economics, s. 75-96; J. Vansina, A Comparison of African Kingdoms, „Africa” 1962, vol. 32, issue 4, s. 324-335; Stownik etnologiczny. Terminy ogólne, red. Z. Staszczak, Poznań 1987; A. Kuper, Wymyślanie społeczeństwa pierwotnego. Transformacje mitu, tłum. T. Sieczkowski, A. Dąbrowska, Kraków 2009, s. 217-219.

${ }_{33} \mathrm{Na}$ temat stosunków politycznych między organizmami Wolofów w połowie XV w., a zwłaszcza zwierzchności Dżolofu nad innymi organizmami wolofskimi: M. Tymowski, Wolof Economy and Political Organization..., s. 132-133, 135; idem, Podróże i poselstwa..., s. 25; idem, Sudan Zachodni od VII do XVI w. [w:] Historia Afryki do poczatku XIX wieku, s. 480-483; The Portuguese in West Africa, 1415-1670, ed. M. Newitt, Cambridge 2010, s. 71; J. Boulègue, Le Grand Jolof (XIIIe-XVIe siecle), Paris 1987; The Cambridge History of Africa, vol. 3: From c. 1050 to c. 1600, ed. R. Oliver, Cambridge 2007, s. 456; J.L.A. Webb Jr., The Horse and Slave Trade between the Western Sahara and Senegambia, „The Journal of African History” 1993, vol. 34, issue 2, s. 225.

34 Roland Oliver pisze, że przez ok. dwa stulecia, prawdopodobnie od drugiej połowy XIV w., państwa Wolofów (Kaior, Walo i Bawol) i Sererów tworzyły „imperium Dżolof” (Djolof empire). Autor twierdzi także, że w połowie XV w. Dżolof rozszerzył swoją władzę na Niomi, Bati, Niani i Wuli, organizmy Malinke położone nad północnym brzegiem Gambii, aby zyskać dostęp do handlu rozwijającego się nad tą rzeką. Badacze nie są jednak w tej sprawie zgodni. Michał Tymowski przekonuje, że organizmy te, choć zapożyczyły od Wolofów typ organizacji politycznej, w czasie podróży Ca' da Mosto pozostawały pod wpływem Mali. Sam Wenecjanin określa je jako ,inne królestwo, zwane Gambra” $(30,266)$. Zob. The Cambridge History of Africa, s. 457; Historia Afryki do poczatku XIX wieku, s. 480, 483-484; Ca' da Mosto - Podróże, s. 51.

35 M. Tymowski, Podróże i poselstwa ..., s. 25.
} 
ściśle powiązane, sprawiały, że wolofscy władcy mogli funkcjonować mimo braku regularnych podatków od ludności ${ }^{36}$.

„Królestwo Senegalu” możemy utożsamiać z położonym w głębi lądu Dżolofem. Władca Dżolofu, noszący tytuł bur-ba, był wybierany z klanu panującego przez radę dostojników, w skład której wchodzili wielki diaraf (szef rady, a zarazem najważniejszy dostojnik dworski), diaraf satle (herold, mówca), wielki farba (naczelnik niewolników władcy) i naczelnicy poszczególnych grup etnicznych. Ważną rolę odgrywały linguere (matka, siostra, ewentualnie krewna władcy ze strony matki) oraz awo (pierwsza żona władcy), nieco mniejsze - tytularni zastępca i następca władcy. Terytorium państwa było zarządzane przez naczelników prowincji i naczelników ważniejszych wiosek. Prowincje, podobnie jak organizmy zależne, składały władcy daninę w naturze cztery razy do roku. Siłę zbrojną władcy stanowiła gwardia niewolników ${ }^{37}$.

Kraj Budomela możemy natomiast utożsamiać z nadmorskim Kaiorem, zachodnim sąsiadem Dżolofu ${ }^{38}$. Władca Kaioru, noszący tytuł damel (Budomel to prawdopodobnie zrost słowa damel oraz oznaczającego władcę w języku Wolofów słowa $\left.b u r^{39}\right)$, był, podobnie jak bur-ba Dżolofu, wybierany przez radę dostojników. Na szczycie hierarchii politycznej znajdowali się członkowie jego rodziny, pełniący funkcje lokalnych naczelników, a zapewne także dowódców wojskowych ${ }^{40}$. Wysoką, w dużej mierze autonomiczną pozycję zajmowali również muzułmanie (Arabowie i Berberowie) oraz chrześcijanie ${ }^{41}$. Podobnie jak bur-ba Dżolofu damel Kaioru nie pobierał stałych podatków, otrzymywał jedynie dary od naczelników wspólnot wiejskich. Damel, choć prawdopodobnie miał swoją główną siedzibę, często podróżował

36 Idem, Wolof Economy and Political Organization..., s. 133-134, 139-140.

37 Zob. Historia Afryki do poczatku XIX wieku, s. 481-482.

38 Dżolof, jako państwo położone w głębi lądu, miał utrudniony dostęp do handlu z Europejczykami. Handel ten otworzył zaś nowe perspektywy przed krajami nadmorskimi, które szybko zaczęły się bogacić i zyskiwać na znaczeniu. W połowie XVI w. jeden z władców Kaioru zbuntował się i pokonał wojska Dżolofu (który był wówczas dodatkowo osłabiony przez konflikt ze wschodnim sąsiadem, Futa Toro). W rezultacie Kaior i związany z nim wówczas Bawol, a do końca stulecia również Walo i inne organizmy wolofskie, uniezależniły się od Dżolofu. Zob. M. Tymowski, Wolof Economy and Political Organization..., s. 133, 139; The Portuguese in West Africa..., s. 67; The Cambridge History of Africa..., s. 457.

39 Władcy Kaioru aż do XIX w. określali się jako bur damel. Tytuły wolofskich władców i dostojników znane nam są głównie z tradycji ustnej. Zob. M. Ty mow ski, Wolof Economy and Political Organization..., s. 133; Historia Afryki do początku XIX wieku, s. 482. W rękopisie A relacji Ca' da Mosto funkcjonuje nazwa Bodumel. Zob. Ca' da Mosto - Podróże, s. 36.

40 Ca' da Mosto wspomina o ważnej roli Bisborora - bratanka Budomela (,pana wioski, w której się właśnie znajdowaliśmy" - 37, 269). Dobrą ilustracją hierarchii społeczno-politycznej w kraju Budomela jest podział terenu wokół wejścia do siedziby władcy na siedem ogrodzonych podwórzy zamieszkanych przez członków jego rodziny - ważniejsi krewni mieszkali najbliżej wejścia, mniej ważni w pewnym oddaleniu $(40,270)$. Innym przykładem jest opis ceremonii audiencji u Budomela (40-42, 270-271). Zob. M. Tymowski, Posypanie glowy piaskiem w ceremoniale dworskim państw Sudanu Zachodniego między XI a XVI wiekiem [w:] Dawne elity - stowo i gest, red. J. Olko, J. Axer, Warszawa 2005, s. 107.

${ }^{41}$ W tym kontekście Ca' da Mosto wspomina o muzułmanach wielokrotnie (np. na s. 40-42, 270 271), o chrześcijanach nieco rzadziej $(40,270)$. O pozycji i roli tzw. marabutów u Wolofów szerzej pisze M. Tymowski, Wenecka uczta... 
po kraju ze swoją drużyną (złożoną z 200 wojowników), zatrzymując się we wspomnianych wcześniej osadach, gdzie wymierzał sprawiedliwość, odbierał dary, korzystał z zapasów i spotykał się ze swoimi żonami.

\section{SŁOWNIK POLITYCZNY CA' DA MOSTO}

1. Lektura Le navigazioni wskazuje, że jedną z podstawowych rzeczy, jakiej starają się dowiedzieć Europejczycy przy pierwszym spotkaniu z Afrykanami, jest to, jak nazywa się ich władca, gdzie rezyduje itp. Ca' da Mosto i jego ludzie pytają ich o to przez thumacza albo polecają mu zdobyć te informacje na lądzie. Ilustruje to na przykład następujący passus dotyczący jednej ze społeczności nad Gambią: „,kazaliśmy wówczas powiedzieć znajdującym się w nim ludziom [Murzynom w czółnie], że atakują nas bez żadnej przyczyny; [...] że przybyliśmy z dalekich krajów, aby ich królowi i panu przekazać dary od naszego króla Portugalii, który pragnie zawrzeć z nimi pokój i przyjaźń; i że prosimy ich, by nam powiedzieli, w jakim kraju się znajdujemy, kto jest jego władcą, jak nazywa się rzeka" $(58-59,280)^{42}$. Jest znamienne, że Wenecjanin zakłada, że spotkani przez niego Afrykanie z pewnością mają jakiegoś władcę.

Pierwszą afrykańską organizacją państwową na południe od Sahary, z którą spotyka się Ca' da Mosto, jest regno di Senega („królestwo Senegalu”), określane także między innymi jako kraj „pierwszych Murzynów” (primi Negri). W całej relacji, poza Senegalem, jedynie Gambia funkcjonuje jako „królestwo” (un altro regno chiamiato Gambra, ,inne królestwo zwane Gambra”) $(30,266)$. Regno to jednak niejedyny termin, jakiego Ca' da Mosto używa na określenie typu i charakteru poszczególnych organizmów politycznych Wolofów. Do pozostałych należą: reame, paese, paesi, stato, luogo, loco. Wszystkie te terminy, łącznie z regno, występują jednak w sposób nierównomierny, częściej lub rzadziej w zależności od tego, którego organizmu dotyczą. W ujęciu sumarycznym najczęściej pojawia się słowo paese i jego liczba mnoga paesi. Jest to też termin najbardziej wieloznaczny, mający konotację zarówno polityczną, jak i geograficzną ${ }^{43}$.

42 Inne przykłady: „Jemu [tłumaczowi] zaś kazał [szlachcic z Genui] się dowiedzieć, jaka jest sytuacja tego kraju i kto jest jego władcą, a także wypytać o złoto i inne interesujące nas rzeczy” (55, 277); „zdecydowaliśmy przygotować dwie łodzie i wysłać na nich na brzeg naszych tłumaczy, poleciwszy im, by dowiedzieli się czegoś o tym kraju, nazwy rzeki oraz imienia pana tej okolicy: tak też uczyniliśmy" $(72,287)$.

43 W Podróżach do Afryki organizmy polityczne Wolofów są określane jako „państwo”, ,królestwo”, „kraj”, „kraina”, „terytorium”, ,,strony”, ,ziemie”. Paese jest tam tłumaczone jako „kraina”, „,terytorium”, „państwo” lub „kraj”. Ostatnie z tych określeń stosowano najczęściej i, jak się wydaje, najlepiej oddaje ono wieloznaczność włoskiego paese. Paesi natomiast tłumaczono jako „strony” lub „ziemie”. Termin regno zawsze, z jednym zaledwie wyjątkiem, przełożono jako „królestwo”, a słowo „królestwo” niemal zawsze stanowi tłumaczenie regno. Tylko raz Joanna Szymanowska tłumaczy regno jako „państwo”, zapewne po to, aby uniknąć powtórzenia (sam autor pisze w tym przypadku il re di questo regno) (39, 269). 
Termin loco, w odniesieniu do organizmów utworzonych przez Wolofów, pojawia się tylko raz - w wyrażeniu loco di Budomel, co można przetłumaczyć jako miejsce, miejscowość lub siedzibę Budomela, ewentualnie jako miejsce, miejscowość, siedzibę „Budomel” $(36,268)^{44}$. Termin paese pojawia się w odniesieniu do kraju Budomela znacznie częściej, na przykład w następujących wyrażeniach: paese di Budomel (,kraj Budomel”) $(36,268)$, paesi del signore Budomel (,ziemie pana Budomela") (51, 276), spazzato da Budomel (,zostawiając za sobą Budomel”) $(51,276)^{45}$. Powyższe przykłady sugerują, że Wenecjanin utożsamia, przynajmniej na poziomie narracyjnym, kraj, którym włada Budomel, z osobą Budomela. W istocie zdaje on sobie jednak sprawę z odrębności w tym zakresie, czemu daje wyraz w następującym zdaniu: „Właściwie Budomel nie jest nazwą kraju, lecz tytułem władcy, a cała ta ziemia nazywa się Budomel jako należąca do tego właśnie pana czy też księcia" (Questo nome Budomel è titolo di signore e non nome proprio del loco, e chiamasi terra di Budomel, come è a dire paese di tal signore over conte) $(36,268)$. Równocześnie przywołane zdanie stanowi wyraz patrymonialnego rozumienia państwa, funkcjonującego również w ówczesnej Europie, gdzie często mówiono o terytorium jakiegoś księcia lub pana ${ }^{46}$.

Termin stato pojawia się w całej relacji tylko dwa razy. Po raz pierwszy spotykamy się z nim w opisie kraju Zucholina: Basta che 'l stato non è stabile e fermo sí come è quello del soldano dal Cairo, ma sta sempre in sospetto d'esser morto over cacciato (266). Polskie thumaczenie tego zdania jest dalekie od dosłowności: „Pozycja króla nie jest zatem mocna i stabilna, jak to ma miejsce w przypadku sułtana Kairu, lecz w każdej chwili może go spotkać śmierć bądź wygnanie" (32) ${ }^{47}$. Po raz drugi stato pojawia się w odniesieniu do kraju Budomela, przy okazji dyskusji, jaką ten prowadzi z Ca' da Mosto o wierze chrześcijan i muzułmanów: E son certo che facilmente s'averia potuto convertire alla fede cristiana, se la paura di perdere il stato non li fusse stata (271); „Pewien jestem, że gdyby nie strach przed utratą państwa, łatwo dałby się nawrócić na wiarę chrześcijańską" (42). We wszystkich pozostałych przypadkach, w zakresie, w jakim mówimy o organizmach politycznych Wolofów, podobnie zresztą jak Sererów i ludów znad Gambii, polskie słowo „państwo” jest thumaczeniem paese. W tekście oryginalnym funkcjonuje zatem, choć tylko w dwóch

44 Polski thumacz pominą jednak to wyrażenie, wprowadzając elipsę. Antonio Marzullo w Dizionario pratico della lingua italiana con esempi didattici e citazioni classiche (Milano 1970, t. 1, s. 616) podaje, że loco to bardziej poetycki synonim luogo, a luogo definiuje następująco: parte circoscritta di spazio | paese, posto, sito ben definiti (s. 621-622).

${ }_{45} \mathrm{~W}$ podobny sposób autor pisze o innych organizmach politycznych, nie tylko wolofskich, np. o organizmie lub regionie Bati - paese del signor Battimansa (,kraj pana Battimansy”) $(71,286)$.

46 W podobny sposób ziemie Polan opisywał Ibrahim Ibn Jakub, żydowski kronikarz, podróżnik i kupiec, który w latach 965-966 odbył podróż do krajów słowiańskich: „A co się tyczy kraju Mesko, to jest on najrozleglejszy z ich krajów”. Zob. Relacja Ibrahima Ibn Jakuba z podróży do krajów słowiańskich w przekazie Al-Bekriego, thum. T. Kowalski, „Monumenta Poloniae Historica”, t. I, seria II, Kraków 1946, s. 50.

47 Bezpośrednio wcześniej czytamy: „Ów król rządzi dopóty, dopóki podoba się panom, co zależy od tego, jak ich traktuje. Często wypędzają go przy użyciu siły, często również dzieje się tak, że król staje się potężny i potrafi się przed nimi obronić" $(32,266)$. 
powyższych przypadkach, wyraźne rozróżnienie między państwem definiowanym w sposób instytucjonalny i abstrakcyjny (stato) a państwem (paese) w tym znaczeniu, które jest bliższe polskiemu słowu „kraj”, a czasem wręcz „ziemie”, a więc mającym wyraźną konotację geograficzną.

Termin „państwo" (francuskie l'Etat, angielskie the state, niemieckie der Staat wszystkie te słowa wykazują wyraźne pokrewieństwo z włoskim lo stato) zaczął być stosowany w Europie w późnym średniowieczu, a upowszechnił się w XVI wieku. Pojawił się on „w językach europejskich wraz z uświadomieniem sobie przez ludzi odrębności dwu instytucji publicznych - osoby władcy oraz publicznoprawnego, społecznego tworu organizacyjnego, którego władca nie jest dysponentem-właścicielem, lecz jedynie najwyższym funkcjonariuszem" ${ }^{48}$. To, że Ca' da Mosto użył terminu stato tylko dwa razy w całej relacji, może zatem świadczyć o dwóch rzeczach. Po pierwsze, o tym, że termin ten nie był wystarczająco zakorzeniony w jego słowniku politycznym. Wenecjanin, jak wiemy, należał do ludzi wykształconych, przy czym jego wiedza miała w dużej mierze wymiar praktyczny - zdobywał ją w czasie wypraw handlowych, najpierw po Morzu Śródziemnym, a potem do Afryki (nie wiemy nic o jego wykształceniu formalnym).

Po drugie, nawet jeśli termin stato miał ugruntowaną pozycję w jego słowniku politycznym, Ca' da Mosto nie zawsze musiał dostrzegać odrębność między instytucją państwa a piastunem najwyższej władzy w państwie, a tym bardziej tę odrębność artykułować, zwłaszcza jeśli nie była ona wyraźna. Wenecjanin wielokrotnie zwraca uwagę, zarówno wprost, jak i implicite, na czynniki ograniczające władzę Budomela i Zucholina, przedstawia w sposób opisowy, a w przypadku Senegalu wręcz wyabstrahowany od osoby aktualnego władcy, mechanizmy sprawowania władzy w państwie. Wydaje się jednak, że liczne inne aspekty funkcjonowania krajów Zucholina i Budomela, zarówno stricte polityczne, jak i społeczno-gospodarcze (np. związki rodzinne jako kryterium doboru członków grupy rządzącej, brak odrębności skarbu państwa od osobistego majątku władcy), skłaniają go do utożsamienia, choćby intuicyjnego, instytucji państwa z osobą jego władcy. W przypadku Budomela czyni tak bardzo często, w przypadku Zucholina znacznie rzadziej.

2. Ca' da Mosto dostrzega, że stojący na czele Senegalu (Dżolofu) Zucholin sprawuje zwierzchność nad Budomelem i jego krajem. Najwyraźniej daje o tym znać w następującym zdaniu: „król tego państwa [il re di questo regno] [Zucholin] posiada jedynie wioski, w których wszystkie domy są ze słomy, a Budomel był władcą tylko jednej, małej części tego królestwa" $(39,269)$. Świadomość owej zwierzchności przejawia się również w doborze terminów na określenie władcy i państwa, które autor różnicuje w zależności od tego, czy pisze o Senegalu i Zucholinie czy o Budomelu.

Wenecjanin wielokrotnie stosuje wyrażenia paese di Budomel lub paesi del signore Budomel. Choć w odniesieniu do kraju Zucholina często używa on słów paese lub paesi, nie tylko w opisie jego geografii, ale także dla ilustracji jego realiów

48 P. Winczorek, Nauka o państwie, Warszawa 2005, s. 57. 
społeczno-politycznych, to ani razu nie łączy ich z imieniem Zucholina - nie pisze, na przykład, paese di Zucholin czy paesi del signore Zucholin (tym bardziej nie łączy imienia Zucholina ze słowami loco czy luogo). W odniesieniu do Senegalu autor stosuje określenia regno lub reame ${ }^{49}$, stato (w jednym przypadku), a także Senega lub regno di Senega, zaś w odniesieniu do kraju Budomela - stato (w jednym przypad$\mathrm{ku}$ ), paese, paesi, luogo i loco. Kraju Budomela ani razu nie określa mianem regno lub reame.

Wskazane różnice powielają się w określeniach władców obu państw. Zucholin jest określany jako re („król”), re di questo regno („,król tego królestwa”) lub re di Senega („król Senegalu”) i tylko dwa razy jako signore i signor (267) (dosłownie „pan”, choć w polskim wydaniu także w tych dwóch przypadkach mamy do czynienia $\mathrm{z}$ „królem”). Budomel jest zaś zawsze określany jako signore (co w polskim wydaniu przekłada się wymiennie na „pan” lub „władca”, ${ }^{50}$ ) - z wyjątkiem jednego przypadku, w którym autor określa go, ale niebezpośrednio, mianem conte („książę") $(36,268)$. Na marginesie zauważmy, że tym samym słowem signore Wenecjanin określa zarówno Budomela, jak i „panów” (w liczbie mnogiej - signori) w państwie Zucholina (tak np. 32, 266) ${ }^{51}$, czyli prawdopodobnie naczelników wspólnot wiejskich, którzy uczestniczyli w wyborze władcy i przekazywali mu dary.

Opisane różnice terminologiczne wynikają z kilku względów. Po pierwsze, Ca' da Mosto pragnie w jakiś sposób zilustrować to, że Senegal i Zucholin sprawują zwierzchność nad Budomelem. Ponieważ w europejskim słowniku politycznym słowa re i regno są związane ze znacznie wyższą, a często także nadrzędną formą organizacji politycznej niż słowa signore czy paese, autor obdarza nimi Senegal i Zucholina. Po drugie, terytorialny zakres władzy Zucholina jest, jak przyznaje sam autor, znacznie większy niż w przypadku Budomela ${ }^{52}$, stąd użycie w odniesieniu do Senegalu słowa regno wydaje się bardziej uzasadnione niż słów loco czy luogo. Po trzecie, być może w oczach autora władza Zucholina, jako zwierzchnia wobec Budomela, ma charakter zbyt abstrakcyjny, aby mógł on utożsamić Zucholina z Senegalem z równą łatwością, jak to uczynił w przypadku Budomela. Nie bez znaczenia jest w tym kontekście to, że Ca' da Mosto nie odwiedził kraju Zucholina, a przynajmniej nic o tym nie wiemy, za to w kraju Budomela spędził on około miesiąca, rozmawiał $\mathrm{z}$ władcą, a nawet, jak możemy wnioskować z jego relacji, darzył go sympatią.

W końcu Ca' da Mosto nazywa Zucholina re, gdyż nie jest w stanie wskazać nikogo, kto sprawowałby władzę zwierzchnią wobec „królów Senegalu”. Jedynym wyjątkiem mogą być tu władcy Mali, o których wspomina on przy okazji opisu władcy

49 Jest to słowo pokrewne $\mathrm{z}$ regno. W relacji występuje ono tylko raz, w znaczeniu tożsamym $\mathrm{z}$ regno $(30,266)$.

50 Wybór słowa, na które tłumaczy się signore (,pan” lub „władca”), wydaje się dowolny. Tego rodzaju podejście jest jednak uzasadnione, biorąc pod uwagę dawniejsze, bardziej wieloznaczne znaczenie słowa signore. Antonio Marzullo (op. cit., t. 2, s. 1087) definiuje je jako [persona] chi aveva dominio su una terra, su un feudo; principe, reggitore, padrone. Zauważmy, że Ca' da Mosto nie stosuje terminu signoria (za Marzullo, op. cit.: potere, dominio politico e morale del signore).

51 Por. M. Tymowski, Wolof Economy and Political Organization..., s. 136.

52 Choć zauważa on, że ,terytorium tego królestwa [Senegalu] jest ograniczone” (32, 266). 
jednego z niewolofskich organizmów nad Gambią (w ramach relacji ze swojej drugiej podróży): „Ów Forosangoli podlegał cesarzowi Mali, który jest wielkim cesarzem Murzynów" (il quale Forosangoli era sottoposto a l'imperatore di Melli, che è il grande imperatore de'Negri) $(66,283)$. Dokonując wyboru między którymś z tych terminów - signore, re i imperatore - Wenecjanin stara się zatem zobrazować zależności między poszczególnymi władcami i ich krajami, a także określić ich miejsce w hierarchii politycznej w regionie.

3. Na szczególną uwagę zasługują także te fragmenty Le navigazioni, w których Ca' da Mosto odnosi się, mniej lub bardziej bezpośrednio, do europejskich zjawisk i instytucji społecznych, gospodarczych i politycznych. Wenecjanin wielokrotnie daje znać, że system społeczno-gospodarczy Wolofów jest odmienny od europejskiego. Przykładowo zauważa, że Wolofowie nie znają pieniędzy i prowadzą handel wymienny, „Król [Senegalu] nie ma stałych przychodów z podatków” $(32,266)$, przez co musi się utrzymywać z „kradzieży niewolników, dokonywanych we własnym kraju oraz w krajach ościennych" $(32,266)^{53}$, a sami Wolofowie nie chcą produkować nadwyżek żywnościowych.

Przede wszystkim jednak $\mathrm{Ca}$ ' da Mosto, jako obywatel jednego z najbogatszych państw ówczesnej Europy, dostrzega, że materialny poziom życia Wolofów jest znacznie niższy niż w Europie, a wolofska gospodarka ma bardzo ograniczone możliwości. Chyba najwyraźniej widać to po tym, w jaki sposób opisuje on targi w „królestwie Senegalu” (gdzie chodził, „żeby zobaczyć coś nowego”) (49, 274): „Dopiero tam, widząc, co owi ludzie przynoszą na sprzedaż, zrozumiałem, jak bardzo są biedni” $(48,274)$; „wszystkiego było tam bardzo mało” $(49,274)$. Ważnym punktem odniesienia w jego percepcji poziomu rozwoju Wolofów jest przy tym stopień urbanizacji. W Senegalu, jak pisze, „nie ma [...] żadnego murowanego miasta, jedynie wioski z domami ze słomy, gdyż nie potrafią oni budować, nie znają zaprawy wapiennej ani nie mają kamienia” $(32,266)$; „Cała ta kraina jest jedną wsią, która mogłaby dawać wspaniałe plony” $(44,272)$. O możnych w Kaiorze wypowiada się z kolei następująco: „,ci, których tam nazywają panami, nie mają zamków ani miast [...]. Wiedzcie zatem, że dom takiego pana nie jest murowany ani nie jest żadnym pałacem" $(39,270)$. Znamienne, że w tym konkretnym przypadku pisze on oględnie „ci, których nazywają tam panami”, a nie, jak w wielu innych miejscach swojej relacji, po prostu ,panowie”.

Ca' da Mosto dostrzega zatem nie tylko biedę poddanych, ale także wyraźnie niższy w stosunku do Europejczyków poziom zamożności miejscowej elity. Zauważmy, że nie okazuje on zachwytu czy choćby podziwu, gdy opisuje, jak Budomel wyjechał na jego powitanie w orszaku złożonym z ,piętnastu ludzi konnych i stu pięćdziesięciu pieszych" $(37,268)$. Dodajmy, że Wenecjanin miał świadomość, że cała drużyna

53 „Ludzie tamtejsi [...] obrabiają ziemię, sieją i zbierają w ciągu trzech miesięcy, a że są bardzo złymi pracownikami, nie chcą się trudzić sianiem większej ilości ziarna ponad tę, która pozwoli im przeżyć następny rok ledwie zaspokajając głód. Nie dbają o to, by mieć coś z tych plonów na sprzedaż" (43-44, 272). 
władcy liczy około 200 osób (40, 270), a konie w Senegambii stanowią symbol bogactwa, władzy i prestiżu $(49-50,275)^{54}$.

Pisząc o „królach Senegalu”, Ca’ da Mosto stwierdza: „Ich król w niczym nie przypomina naszych królów chrześcijańskich, bowiem w jego królestwie poddanymi są ludzie dzicy i nic nie posiadający" $(32,266)$. Chociaż Wenecjanin wielokrotnie chwali talenty Afrykanów ${ }^{55}$, to równie często zwraca on uwagę na „dzikie”, jak mógłby to ująć, zachowania Wolofów: „Większość tych ludzi chodzi nago, za jedyny przyodziewek mając kozią skórę upiętą na modłę spodni, którą osłaniają wstydliwe części ciała” (34, 267); ,jedzą z ziemi jak zwierzęta” (43, 271); „mordują się więc bez opamiętania jak dzikie bestie" $(35,268)$.

Michał Tymowski zauważa: „W najwcześniejszych przekazach opinia o barbarzyństwie, nawet bestialstwie ludów Afryki była częsta i wyrażana dobitnie ze względu na tryb życia, rodzaj pożywienia, nagość i pogaństwo. Jednakże dotarcie od połowy XV w. do państw afrykańskich, poznanie tamtejszych form organizacji, nawiązanie kontaktów handlowych z władcami i kupiectwem, spowodowało skorygowanie tych opinii: albo ich zmianę, albo - najczęściej - zróżnicowanie. [...] Cechę tę [barbarzyństwo] powiązano natomiast z pogaństwem" ${ }^{56}$. Wydaje się, że relacja $\mathrm{Ca}$ ' da Mosto, zawierająca zarówno słowa krytyczne, jak i pochwały pod adresem Afrykanów, wpisuje się w owo zróżnicowanie, o którym pisze Tymowski. Przywoływane porównanie do „królów chrześcijańskich” wskazuje przy tym, że punktem odniesienia w opisie władzy u Wolofów jest dla Wenecjanina Europa chrześcijańska, rozumiana jednak nie tyle jako wspólnota określonych wartości religijnych, ile jako świat wysokiej kultury duchowej i materialnej, ,świat cywilizowany”, będący przeciwieństwem świata ludzi „dzikich i nic nie posiadających”.

$\mathrm{Ca}^{\prime}$ da Mosto dostrzega znaczne dysproporcje w dostępie do dóbr materialnych, a nawet pożywienia, między władcą a poddanymi, także tymi z jego bliskiego otoczenia. „[Król] zjada to, na co ma ochotę, a resztę oddaje ludziom, którzy z nim przybyli - ale nigdy tyle, by najedli się do syta, więc chodzą stale głodni” $(33,267)$ pisze o Zucholinie i jego świcie. Wenecjanin informuje zresztą, że na niski, w porównaniu z Europejczykami, poziom zamożności Afrykanów zwracał uwagę także sam Budomel: ,utrzymywał też, że byłoby rozsądne, gdyby to raczej oni, Murzyni, zostali zbawieni, a nie chrześcijanie, bowiem Bóg jest panem sprawiedliwym, więc jeśli nam dał tyle dóbr i rozmaitych rzeczy na tym świecie, a im w porównaniu z nami nieomal nic, jeśli zatem nam dał raj tutaj, to oni powinni mieć go na tamtym świecie" $(42,271)$.

54 Zob. J.L.A. Webb Jr., op. cit.; R. Law, Horses, Firearms, and Political Power in Pre-Colonial West Africa, „Past \& Present” 1976, vol. 72; I. Elbl, The Horse in Fifteenth-Century Senegambia, „The International Journal of African Historical Studies" 1991, vol. 24, no. 1.

55 „Wykonując rzeczy, do których nie są przyzwyczajeni, są prostaccy i niezdarni, ale te, z którymi są obyci, robią tak samo dobrze jak my” $(35,268)$; „Murzyni ci są najlepszymi na świecie pływakami” $(36,268)$; „Piłem to wino przez wiele dni mego pobytu w głębi tego kraju i smakowało mi lepiej niż nasze" $(44,272)$.

56 M. Tymowski, Podróże i poselstwa..., s. 37-38. Zob. także: T. Farrar, When African Kings Became 'Chiefs': Some Transformations in European Perceptions of West African Civilization, c. 1450 1800, „Journal of Black Studies” 1992, vol. 23, no. 2. 
Zarazem Ca' da Mosto zdaje sobie sprawę, że legitymizacja władzy Zucholina i Budomela wynika nie tylko z ich przewagi ekonomicznej nad poddanymi. Jego zdaniem: „Ludzie ci [miejscowi panowie] nie są panami [signori] ze względu na bogactwa ani pieniądze, których nie mają, bo nie używa się tam żadnych pieniędzy; o ich randze świadczy ceremoniał, jakim są otoczeni, oraz liczna świta, która wszędzie im towarzyszy. Cieszą się powszechnym poważaniem i budzą u swych poddanych o wiele większy lęk niż panowie w naszych krajach [i nostri signori di qua]" (39, 270). Autor rozwija tę myśl w ramach opisu audiencji u Budomela, który „tyle zaś pokazuje przy tym wyniosłości i wyższości, i tak bardzo jest tam poważany, że gdyby sam Pan Bóg pojawił się na ziemi, to sądzę, że nikt by go nie czcił i nie poważał tak, jak ci Murzyni czczą swego pana. Wydaje mi się, że to wszystko wynika z wielkiego strachu, jaki żywią owe ludy wobec swych panów, ponieważ z powodu najmniejszego nawet uchybienia pan może odebrać im i sprzedać żonę i dzieci. Sądzę więc, że pana można tam poznać po dwu następujących rzeczach: po orszaku ludzi, którzy mu towarzyszą, oraz po tym, że rzadko pozwala się oglądać; no i jeszcze po tym, że poddani otaczają go wielką czcią" $(41,270-271)^{57}$.

\section{PODSUMOWANIE}

Homo sapiens to homo categoricus. Nawet jeśli dane zjawisko czy instytucja wydają nam się odmienne od wszystkiego, co widzieliśmy wcześniej, czujemy potrzebę wpisania ich w ramy znanych kategoriii ${ }^{58}$. Ca' da Mosto wyruszał do Afryki, jak sam przyznaje, „spragniony ujrzenia na świecie rzeczy, których nie oglądał nikt z moich rodaków" $(10,257)$. Aby je poznać, zrozumieć, oswoić i opisać w czytelny, ale i atrakcyjny sposób, porównuje je do znanej sobie rzeczywistości. Przykładowo stwierdza, „że mężczyźni w tamtych krajach wykonują wiele prac kobiecych” (34, 267), a Murzyni z Gambii noszą „,białe kapelusiki podobne nieco do niemieckich” $(58,269)$. O słoniach, których nie spotkał nigdy wcześniej, pisze, że „chodzą tam stadami, jak u nas dziki w lasach" $(46,273)$, a hipopotama, który przypomina mu rybę, konia lub dzika, określa mianem rybokonia (pesce cavallo) $(71,286)$. Czasami żeglarz odwołuje się do obrazów z rodzinnej Wenecji - łódki Afrykanów przypominają mu „,nasze almadie” lub „nasze zoppoli, tyle że bardzo duże” (76, 290), a ich instrument „małą violę, taką, na jakich my gramy, posługując się smyczkiem” $(51,276)$. Punktem odniesienia bywają również państwa muzułmańskie w Afryce Północnej

57 Ca' da Mosto pisze, że „Budomel odznaczał się wyniosłością i powagą, które nie pozwalały mu pokazywać się częściej niż przez jedną godzinę rano i jeszcze trochę przed wieczorem" $(40,270)$. Autor dodaje, że „Wszyscy tamtejsi panowie udzielają audiencji z zachowaniem całego ceremoniału” (40, 270).

58 H. de Soto, Bieda może pokochać kapitalizm, „Newsweek” 2003, nr 51-52. 
i w regionie Sudanu Zachodniego - przykładem może być porównanie słabej władzy Zucholina do silnej władzy „sułtana Kairu” $(32,266)^{59}$.

Choć Ca' da Mosto nie znał miejscowych języków, to zdawał sobie sprawę z ograniczeń związanych ze stosowaniem do opisu życia Afrykanów słów i wyrażeń $\mathrm{z}$ europejskiego słownika politycznego. Widać to choćby w tym, że nieraz niuansuje on ich znaczenie lub czyni w stosunku do nich pewne zastrzeżenia, zarówno w sposób stanowczy i bezpośredni („Ich król w niczym nie przypomina naszych królów chrześcijańskich” - 32, 266), jak i bardziej delikatnie („Pozycja króla nie jest zatem mocna i stabilna, jak to ma miejsce w przypadku sułtana Kairu" - 32). Poszukując źródeł jego postawy w tym zakresie, należy się zgodzić z poglądem, w myśl którego wiedza o nieprzystawalności znaczeń podobnych pojęć, powstałych i funkcjonujących w ramach odrębnych języków i kultur, jest stara, uniwersalna i intuicyjnie wyczuwalna $^{60}$. Z pewnością duży wpływ miały także jego dotychczasowe doświadczenia w kontaktach z innymi kulturami, zdobyte w czasie licznych podróży kupieckich, a także takie cechy charakteru jak otwartość i krytycyzm.

W konsekwencji to, że Wenecjanin opisuje afrykańskie realia polityczne takimi słowami jak re czy regno, mimo że dostrzega on znaczne różnice w stopniu zamożności oraz sposobie organizacji politycznej i społeczno-gospodarczej, jakie występują między Afrykanami a Europejczykami, na poziomie zarówno elity, jak i niższych warstw społecznych, świadczy o co najmniej dwóch rzeczach. Po pierwsze o tym, że słowa te mają dla niego charakter umowny, po drugie zaś o tym, że za najważniejsze metody lub przejawy legitymizacji władców wolofskich, upodabniające ich do przynajmniej niektórych królów i książąt europejskich, uznaje on te o charakterze niematerialnym. Wśród nich szczególne miejsce zajmują ściśle określony ceremoniał, niedostępność władców, powaga i cześć, jakimi są oni obdarzani, oraz - większy niż w przypadku „panów w naszych krajach” - strach, jaki budzą wśród poddanych.

\section{BIBLIOGRAFIA}

\section{Źródła}

Ca' da Mosto A. da, Le navigazioni di Alvise da Ca'da Mosto e Pietro di Sintra [w:] G.B. Ramusio, Navigazioni e viaggi, t. 1, a cura di M. Milanesi, Torino 1978.

59 Nie rzadziej $\mathrm{Ca}$ ' da Mosto odwołuje się do niemuzułmańskich organizmów politycznych na południe od Sahary, np. w zdaniu: „Prawie wszyscy prowadzą taki sam tryb życia jak Murzyni z Senegalu, jadają takie same potrawy, tyle że mają więcej ryżu różnych odmian, takich, które nie rosną w poprzednim murzyńskim królestwie" $(68,285)$. Taka technika narracyjna wynika po części z tego, że Senegal był pierwszym na jego drodze krajem zamieszkanym przez czarnych Afrykanów (określa on go jako kraj „pierwszych Murzynów”, primi Negri), w którym zdobył on zresztą wiele informacji na temat ludów żyjących na południu.

60 A. Wierzbicka, Stowa klucze. Różne języki - różne kultury, thum. I. Duraj-Nowosielska, Warszawa 2007, s. 20-21. 
Ca’ da Mosto A. da, Podróże do Afryki, tłum. J. Szymanowska, wstęp i oprac. M. Tymowski, Gdańsk 1994.

Europeans in West Africa 1450-1560, ed. and transl. J.W. Blake, London 1967.

Marees P. de, Description and Historical Account of the Gold Kingdom of Guinea (1602), ed. and transl. A. van Dantzig, A. Jones, Oxford 1987.

The Portuguese in West Africa, 1415-1670, ed. M. Newitt, Cambridge 2010.

Ramusio G.B., Il viaggio di Giovan Leone e le navigazioni di Alvise da Ca da Mosto, di Pietro di Cintra, di Annone, di un piloto portoghese e di Vasco di Gama, Venezia 1837.

Relacja Ibrahima Ibn Jakuba z podróży do krajów słowiańskich w przekazie Al-Bekriego, t. I, seria II, tłum. T. Kowalski, „Monumenta Poloniae Historica”, Kraków 1946.

The Voyages of Ca' da Mosto and Other Documents on Western Africa in the Second Half of the Fifteenth Century, ed. and transl. G.R. Crone, London 1936.

Zurara G.E., The Chronicle of the Discovery and Conquest of Guinea, ed. Ch. Beazley, London-New York 1896.

\section{Monografie i prace zbiorowe}

Boulègue J., Le Grand Jolof (XIIIe-XVIe siecle), Paris 1987.

The Cambridge History of Africa, vol. 3: From c. 1050 to c. 1600, ed. R. Oliver, Cambridge 2007.

Da Silva J.G., Morskie dzieje Portugalczyków, tłum. V. Soczewińska, red. nauk. J. Kieniewicz, Gdańsk 1987.

Historia Afryki do początku XIX wieku, red. M. Tymowski, Wrocław 1996.

Kuper A., Wymyślanie spoteczeństwa pierwotnego. Transformacje mitu, thum. T. Sieczkowski, A. Dąbrowska, Kraków 2009.

Małowist M., Europa a Afryka Zachodnia w dobie wczesnej ekspansji kolonialnej, Warszawa 1969.

Małowist M., Konkwistadorzy portugalscy, Warszawa 1976.

Tymowski M., Państwa Afryki przedkolonialnej, Wrocław 1999.

Whitfield P., The Image of the World: 20 Centuries of World Map, London 2010.

Wierzbicka A., Słowa klucze. Różne języki - różne kultury, thum. I. Duraj-Nowosielska, Warszawa 2007.

Winczorek P., Nauka o państwie, Warszawa 2005.

\section{Artykuły}

Elbl I., Cross-Cultural Trade and Diplomacy: Portuguese Relations with West Africa, 14411521, „Journal of World History” 1992, vol. 3, no. 2.

Elbl I., The Horse in Fifteenth-Century Senegambia, „The International Journal of African Historical Studies" 1991, vol. 24, no. 1.

Farrar T., When African Kings Became 'Chiefs': Some Transformations in European Perceptions of West African Civilization, c. 1450-1800, „Journal of Black Studies” 1992, vol. 23 , no. 2.

Hair P., Early Sources on Guinea, „History in Africa” 1994, vol. 21. 
Kimble G.H.T., Portuguese Policy and Its Influence on Fifteenth Century Cartography, „Geographical Review” 1933, vol. 23, no. 4.

Law R., Horses, Firearms, and Political Power in Pre-Colonial West Africa, „Past \& Present" 1976, vol. 72.

Soto H. de, Bieda może pokochać kapitalizm, „Newsweek” 2003, nr 51-52.

Southall A., The Segmentary State: From the Imaginary to the Material Means of Production [w:] Early State Economics, ed. H.J.M. Claessen, P. van de Velde, New Brunswick-London 1991.

Tymowski M., Europeans and Africans in the Early Period of Portuguese Expansion in Africa - the Organization and Course of the First Encounters, „Hemispheres” 2010, vol. 25 .

Tymow ski M., Jak w XV wieku europejscy odkrywcy porozumiewali się z Afrykanami? [w:] Człowiek w społeczeństwie średniowiecznym, red. R. Michałowski, Warszawa 1997.

Tymowski M., Odkrywanie świata przez Europejczyków w XIV-XV w. [w:] Schylek średniowiecznej Europy, red. H. Samsonowicz, Warszawa 2003.

Tymowski M., Opinie Afrykanów o Europejczykach we wczesnym okresie wypraw portugalskich do Afryki Zachodniej (XV w.-poczatek XVI w.) [w:] Ex Africa semper aliquid novi, t. I, red. J. Łapott, E. Prądzyńska, Żory 2014.

Tymowski M., Państwo i plemię w dziejach Afryki Czarnej [w:] Plemię, państwo, demokracja. Uwarunkowania kultury politycznej w krajach pozaeuropejskich, red. R. Vorbrich, Poznań 2007.

Tymowski M., Podróże i poselstwa władców zachodnioafrykańskich do Portugalii w XVw., „Afryka” 2014, nr 40.

Tymowski M., Posypanie głowy piaskiem w ceremoniale dworskim państw Sudanu Zachodniego między XI a XVI wiekiem [w:] Dawne elity - stowo i gest, red. J. Olko, J. Axer, Warszawa 2005.

Tymowski M., Przestrzenne ramy handlu europejsko-afrykańskiego na Wybrzeżu Zachodnim Afryki w XV i na początku XVI wieku (opisy i źródła ikonograficzne) [w:] Świat średniowiecza. Studia ofiarowane Profesorowi Henrykowi Samsonowiczowi, red. A. Bartoszewicz, G. Myśliwski, J. Pysiak, P. Żmudzki, Warszawa 2010.

Tymow ski M., State and Tribe in the History of Medieval Europe and Black Africa-a Comparative Approach, „Social Evolution and History” 2008, vol. 7, no. 1.

Tymowski M., Strach i odwaga w czasie pierwszych wypraw europejskich do Afryki w XV w., „Przegląd Historyczny” 2006, nr 97, z. 3.

Tymowski M., Wenecka uczta na wybrzeżu Afryki Zachodniej w połowie XV wieku [w:] Aetas media, aetas moderna. Studia ofiarowane profesorowi Henrykowi Samsonowiczowi w siedemdziesiąta rocznice urodzin, red. H. Manikowska, A. Bartoszewicz, W. Fałkowski, Warszawa 2000.

Tymowski M., Wolof Economy and Political Organization: The West African Coast in the Mid-Fifteenth Century [w:] Early State Economics, ed. H.J.M. Claes sen, P. van de Velde, New Brunswick-London 2009.

Vansina J., A Comparison of African Kingdoms, „Africa” 1962, vol. 32, issue 4.

Webb J.L.A. Jr., The Horse and Slave Trade between the Western Sahara and Senegambia, „The Journal of African History” 1993, vol. 34, issue 2. 


\section{Słowniki}

Marzullo A., Dizionario pratico della lingua italiana con esempi didattici e citazioni classiche, Milano 1970.

Słownik etnologiczny. Terminy ogólne, red. Z. Staszczak, Poznań 1987. 